SECURITY CLASSIFICATION OF THIS PAGE (When Data Entered)

\begin{tabular}{|c|c|}
\hline REPORT DOCUMENTATION PAGE & $\begin{array}{l}\text { READ INSTRUCTIONS } \\
\text { BEFORE COMPLETING FORM }\end{array}$ \\
\hline $\begin{array}{l}\text { 1. REPORT NUMBER } \\
\text { Miscellaneous Paper GL }-84-12\end{array}$ & 3. RECIPIENT'S CATALOG NUMBER \\
\hline \multirow[t]{2}{*}{$\begin{array}{l}\text { 4. TITLE (and Subtitle) } \\
\text { SOIL DESTABILIZATION FOR VEHICLE BARRIERS }\end{array}$} & $\begin{array}{l}\text { 5. TYPE OF REPORT \& PERIOD COVERED } \\
\text { Final report }\end{array}$ \\
\hline & 6. PERFORMING ORG. REPORT NUMBER \\
\hline $\begin{array}{l}\text { 7. AUTHOR(s) } \\
\text { Harry G. Brown and Walter R. Barker }\end{array}$ & 8. CONTRACT OR GRANT NUMBER(B) \\
\hline $\begin{array}{l}\text { 9. PERFORMING ORGANIZATION NAME AND ADDRESS } \\
\text { U. S. Army Engineer Waterways Experiment Station } \\
\text { Geotechnical Laboratory } \\
\text { P. O. BOX } 631 \text {, Vicksburg, Mississippi } 39180\end{array}$ & $\begin{array}{l}\text { 10. PROGRAM ELEMENT. PROJECT, TASK } \\
\text { AREA \& WORK UNIT NUMBERS } \\
\text { ILIR Project } 4 \text { A161101A91D, } \\
\text { Task 02, Work Unit } 149\end{array}$ \\
\hline \multirow{2}{*}{$\begin{array}{l}\text { 11. CONTROLLING OFFICE NAME AND ADDRESS } \\
\text { Assistant Secretary of the Army (R\&D) } \\
\text { Department of the Army } \\
\text { Washington, DC } 20310\end{array}$} & $\begin{array}{l}\text { 12. REPORT DATE } \\
\text { July } 1984\end{array}$ \\
\hline & $\begin{array}{l}\text { 13. NUMBER OF PAGES } \\
21\end{array}$ \\
\hline \multirow[t]{2}{*}{ 14. MONITORING AGENCY NAME \& ADDRESS(if different from Controliting Office) } & $\begin{array}{l}\text { 15. SECURITY CLASS. (of this roport) } \\
\text { Unclassified }\end{array}$ \\
\hline & $\begin{array}{l}\text { 15a. DECLASSIFICATION/DOWNGRADING } \\
\text { SCHEDULE }\end{array}$ \\
\hline
\end{tabular}

Approved for public release; distribution unlimited.

17. DISTRIBUTION STATEMENT (of the abstract onterod in Block 20, if different from Report)

18. SUPPLEMENTARY NOTES

Available for National Technical Information Service, 5285 Royal Road, Springfield, Virginia 22161.

19. KEY WORDS (Continue on feverse side if necessary and identify by block number)

Hydro-Gel

Soft Soil

Soil Destabilization

Vehicle Barriers

20. ABSTAACT (Couthue an reverae oida if necesasy and identity by block number)

Soil destabilization tests were conducted at the U. S. Army Engineer Waterways Experiment Station to investigate the feasibility of constructing soft-soil vehicle barriers. Six test pits and one vehicle trap were constructed using a water-retaining agent (Hydro-Gel). Test results showed that soft-soil areas could be constructed to serve as vehicle barriers. However, additional research is needed to develop a more suitable moisture-retaining material because of the seepage and wicking that occurred with the Hydro-Gel. 
The study reported herein was performed by the Geotechnical Laboratory (GL), U. S. Army Engineer Waterways Experiment Station (WES), during the period April to August 1983 under the In-House Laboratory Independent Research (ILIR) Program as Project 4A161101A91D, Task Area 02, Work Unit 149, sponsored by the Assistant Secretary of the Army (R\&D).

The study was conducted under the general direction of Dr. W. F. Marcuson III, Chief, GL, and under the direct supervision of Dr. T. D. White, Chief, Pavement Systems Division (PSD), GL. Engineers and technicians of the PSD actively engaged in planning, testing, analyzing, and reporting phases of this study were Dr. W. R. Barker and Mr. H. G. Brown. This report was prepared by $\mathrm{Mr}$. Brown and Dr. Barker.

Commander and Director of the WES during the course of this study and preparation and publication of this report was COL Tilford C. Creel, CE. The Technical Director was Mr. Fred R. Brown. 
PREFACE . . . . . . . . . . . . . . . . . . . . . . . .

CONVERSION FACTORS, U. S. CUSTOMARY TO METRIC (SI)

UNITS OF MEASUREMENT .

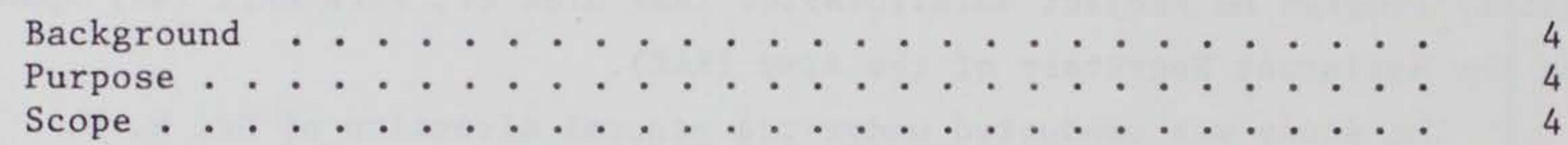

PART II: LABORATORY TESTS ..................... . . . 5

Material Description ................ 5

Mixing Procedure .................. 5

Mixture Consistency . . . . . . . . . . . . . . . 6

PART III: SMALL TEST PITS . . . . . . . . . . . . . . . 7

PART IV: VEHICLE BARRIERS ....................... . . . 9

Construction ..................... . . . 9

Testing . . . . . . . . . . . . . . . . . . . 10

Discussion . . . . . . . . . . . . . . . . . . 10

PART V: CONCLUSIONS AND RECOMMENDATIONS. . . . . . . . . . . . . 11

Conclusions . . . . . . . . . . . . . . . . . . . 11

Recommendations . . . . . . . . . . . . . . . 11

TABLES $1-3$

FIGURES $1-5$

PHOTOS 1-11 
CONVERSION FACTORS, U. S. CUSTOMARY TO METRIC (SI)

UNITS OF MEASUREMENT

U. S. customary units of measurement used in this report can be converted to metric (SI) units as follows:

Multiply

feet

inches

pounds (mass)

tons $(2,000$ pounds, mass)

\begin{tabular}{c}
$\frac{1}{\text { By }}$ \\
\hline 0.3048 \\
2.54 \\
0.4535924 \\
907.1847
\end{tabular}

To Obtain metres

centimetres

kilograms

kilograms 


\section{PART I: INTRODUCTION}

\section{Background}

1. Swampy areas and/or areas of soft soils have long been recognized as barriers to the movement of nearly all types of vehicles. In warfare such areas can be a major advantage in the development of defensive positions; this being particularly true if the opposing forces are unaware of untraversable areas. Unfortunately, for most defensive positions naturally occurring swampy areas and/or areas of soft soils are not available or are not located in positions to provide necessary barriers for best defense.

2. Barriers, consisting of fencing, walls, ditches, minefields, etc., are usually constructed to help provide for the defense of fixed positions. These types of barriers have several disadvantages among which are visibility, cost, construction time, and vulnerability. If artificial barriers of soft soil could be created, these barriers could be located to supplement other barriers and enhance defensive positions. Soft-soil barriers could have the advantage of being hidden and having an increased effectiveness against heavier vehicles.

\section{$\underline{\text { Purpose }}$}

3. The purpose of this investigation was to study the possible application of a water-retaining material in the construction of soft-soil vehicle barriers.

\section{$\underline{\text { Scope }}$}

4. The investigation included a laboratory study to determine (a) how well a particular water-retaining material mixed with water; (b) the proportions needed to obtain a firm, gelatin-like material, and (c) the possibility of using an extender such as sand or clay. A field study was also included to determine how the material would behave in an open environment. 


\section{PART II: LABORATORY TESTS}

\section{Material Description}

5. The water-retaining material investigated is a product produced by Finn Corporation, Cincinnati, Ohio, having the trade name Hydro-Gel. HydroGel is a yellowish white power advertised as being capable of absorbing and maintaining up to 1000 times its weight in water. The product is sold primarily as a plant watering aid for agricultural applications.

6. The objective of the laboratory testing was to determine the best procedure for mixing the Hydro-Gel with water and the proportions needed to obtain proper gel consistency. The laboratory test was conducted by mixing Hydro-Gel and water in different proportions in a jar with a capacity of approximately $1600 \mathrm{ml}$ * The proportions used were 15, 30, and $100 \mathrm{ml}$ of Hydro-Gel to approximately $1500 \mathrm{ml}$ of water. These proportions correspond to mixtures of $0.3,1.0$, and 3.3 percent Hydro-Ge1 by weight.

7. In three mixtures sand was used as a filler. For these mixtures 50, 100 , and $200 \mathrm{ml}$ of sand were added to the water and Hydro-Gel. The application of sand appeared to serve no useful purpose, and no further reporting of these tests will be made.

\section{$\underline{\text { Mixing Procedure }}$}

8. Three techniques of mixing the Hydro-Gel and water were tried. In the first procedure, the measured amount of Hydro-Gel was placed in the jar and a sufficient amount of water was poured on the Hydro-Gel to yield $1500 \mathrm{ml}$ of mixture. In this procedure, the Hydro-Gel firmed and formed lumps in the bottom of the jar resulting in an inconsistent mixture from the top to the bottom. The top of the mixture was watery and the bottom was very firm with lumps of dry Hydro-Gel in the bottom of the jar. The reaction between the water and the Hydro-Gel was very rapid with the Hydro-Gel almost completely absorbing the water in less than $1 \mathrm{~min}$. In the second mixing procedure,

* For convenience, volume measurements were made using the metric (SI) unit millilitres, while all other measurements were made using U. S. customary units. If conversion from millilitres is desired, multiply the number of millilitres by 0.0338176 to obtain ounces (U. S. fluid). 
approximately $1500 \mathrm{ml}$ of water was placed in the jar, and a measured amount of Hydro-Gel was poured into the water. During the pouring of the Hydro-Gel, the mixture was stirred continuously. This procedure was an improvement over the first procedure but still was not entirely satisfactory. For mixture having higher proportions of Hydro-Gel, the surface firmed before the mixing could be completed. The mixture would then be left with excess Hydro-Gel at the surface. The final procedure, the procedure deemed satisfactory, was where the water and Hydro-Gel were poured in the jar simultaneously. The pouring required less than 1 min and resulted in a uniform mixture from top to bottom. The absorption of water was completed in 1 to $2 \mathrm{~min}$ after the pouring was completed.

\section{Mixture Consistency}

9. Of the three mixtures, the one having 1.0 percent Hydro-Gel by weight appeared to have the consistency of a stiff gelatin and was the most uniform mixture. The mixture with 0.3 percent Hydro-Gel had a watery consistency with separation between water and gel occurring with time. The mixture with 3.3 percent Hydro-Gel contained dry powder in lumps and thus appeared to have an excess of Hydro-Gel. After several weeks both the 1.0 percent mixture and the 3.3 percent mixture maintained the original consistency. Using the results of the jar mixtures, the 1.0 percent mixture was chosen as the mixture to use in the field study. 
10. The field investigation was conducted in two phases. The first phase consisted of the construction of 6 test pits, and the second phase was testing of the vehicle barrier that will be discussed later in this report. Each pit was $2-\mathrm{ft} *$ by $2-\mathrm{ft}$ deep excavated in a loess (CL) $* *$ type soil. The purpose of the study was to evaluate the behavior of the Hydro-Gel in an open environment and to develop a method for construction of a vehicle barrier.

11. Pits 1,2 , and 3 were unlined, while pits 4,5 , and 6 were lined with a polyethylene membrane. The membrane liner was used to prevent the water from escaping through the sides of the pits. Pits 1 and 4 were filled to the top with gel. Pits 2 and 5 contained 18 in. of gel covered with 6 in. of soil (CL). Pits 3 and 6 contained $12 \mathrm{in}$. of gel covered with $12 \mathrm{in}$. of soil. The soil covering provided support capacity to the gel and to camouflage a true barrier. The cross sections of the pits are shown in Figure 1.

12. The Hydro-Gel and water were placed in the pits using the procedure developed in the laboratory testing. Photo 1 illustrates the placing of the Hydro-Gel in a lined pit. Using this procedure, the Hydro-Gel was easily placed in the pit, and the soil was carefully placed and lightly compacted in pits 2, 3, 5, and 6 . For pits 2 and 5 (pits having a soil covering of 6 in.), the soil, after compaction, was firm but would not support a person. Pits 3 and 6 (with the soil covering of 12 in.) were capable of supporting a person. Cone penetrometer measurements were taken in each pit and results are shown in Table 1. The gel did not have sufficient strength to register on the penetrometer (pits 1 and 4). The higher cone index measurements for pits 3 and 6 reflect the higher strength of the soil covering.

13. The surface areas of the pits were monitored for a period of time to determine the loss of water. The drop in the surface elevation of the pits with time is given in Table 2 .

14. The data in Table 2 clearly indicate that the drops in the surfaces of the pits were much greater for the unlined pits than for the lined pits. This fact is illustrated in Figures 2, 3, and 4 which compare the surface

* A table of factors for converting U. S. customary units of measurement to metric (SI) units is presented on page 3 .

** Classified by the Unified Soil Classification system. 
drops between pits 1 and 4, pits 2 and 5, and pits 3 and 6 , respectively. From these data, it is obvious that a considerable amount of water from the unlined pits was lost into the surrounding soil. This indicates that in order for the Hydro-Gel to maintain the water for an extended time in an actual vehicle barrier, the pits would require an impermeable liner. Also, for the surface of the barrier to have sufficient strength to support human travel a soil covering of at least $12 \mathrm{in.}$ is required. 


\section{Construction}

15. The cross section of the vehicle barrier as constructed is shown in Figure 5. The pit was dug to the dimensions shown (Figure 5) using a dozer and backhoe. The ends were sloped to allow the entry of a vehicle without causing damage to the vehicle or endangering operating personnel. The pit was then lined with a polyethylene liner (Photo 2). The Hydro-Gel and water were then poured into the pit simultaneously as shown in Photo 3. The gel was placed in approximately about 5 min with solidification occurring almost simultaneously with the placement. The pit, after placement of the gel, is shown in Photo 4. Immediately after placement of the gel, covering the gel with soil (CL) was started. First, a layer of soil about 3 in. thick was carefully placed by hand (Photos 5 and 6 ). This type of placement was necessary to prevent displacement of the gel by the soil. With an initial layer of soil completely covering the gel, a front-end loader was then used to complete placement of the soil over the gel. The completed vehicle barrier is shown in Photo 7. The surface of the soil had sufficient strength to support human traffic, as exhibited in Photo 8 by the footprints.

16. After several days, the surface of the soil covering began to appear moist. The area of moist soil continued to increase until the entire area of the pit looked wet (Photo 9), even though the weather was hot and dry.

17. From viewing the appearance of the surface, it was obvious that the water was being wicked from the gel and lost by evaporation. During the two weeks between construction and testing of the barrier, the surface of the soil covering the surface of the gel had dropped about $6 \mathrm{in}$.

18. Prior to testing, cone penetrometer readings were taken at the center of the pit (Table 3). The strength profile for the vehicle barrier was similar to the strength profiles for the 2- by 2- by 2-ft test pits. Even though the soil covering had become very wet, the surface maintained sufficient strength to support a person. 


\section{Testing}

19. Two weeks after construction, the barrier was tested using a 5-ton $6 \times 6$ military cargo truck. The truck was driven into the barrier from one of the ramped ends. The truck immediately displaced the soil surface and was stopped about one-third of the way through the barrier. The position of the truck and the condition of the barrier when forward progress of the truck was stopped are shown in Photos 10 and 11. Although its forward progress was stopped, the truck was able to back out of the barrier without assistance. Since the barrier was constructed with ramps to prevent damage to the vehicle, its effectiveness was greatly diminished. If not for the ramps, it is expected that the vehicle would have been completely immobilized.

\section{Discussion}

20. This investigation demonstrated that soft-soil areas could be constructed to serve as vehicle barriers. Without considering cost, Hydro-Gel was found to be satisfactory for the construction of a barrier with a short life span. The material was easily mixed with water, required only 1.0 percent Hydro-Gel to form the gel, immediately absorbed water, and was easily handled. One drawback of Hydro-Gel is that is does not hold water for extending periods of time. Water was lost by evaporation and wicking into the surrounding soil. The loss of water was reduced by the use of impermeable liner in the bottom and on the sides of the pits, but the loss through the surface was significant. It is probable that the loss could be further reduced by the use of a liner over the surface. Another drawback in the use of Hydro-Gel is that the gel is so weak that the soil cover must be placed with great care. To allow for machine backfilling over the gel would require a gel having a higher strength. Although the disadvantages of Hydro-Gel may preclude its use in vehicle barriers, the testing of this material could be a starting point toward the development of an effective vehicle barrier. 


\section{Conclusions}

21. The laboratory and field tests conducted in this investigation are the basis for the following conclusions:

a. Soft-soil areas can be readily constructed as an effective vehicle barrier with a short life.

b. The long-term maintenance of soft-soil barriers will be difficult and would probably require construction using membranes as liners to prevent loss of water.

c. The use of Hydro-Gel has disadvantages that may preclude its use in vehicular barriers.

d. The development of an effective soft-soil vehicle barrier is possible, but would require additional research on water-retaining agents and field construction.

\section{$\underline{\text { Recommendations }}$}

22. To meet the need for vehicle barriers, it is recommended that additional research be undertaken to develop soft-soil barriers. Such research could be divided into the following areas:

a. Study of water-retaining agents for providing soft soils.

b. Development of optimum barrier geometry.

c. Development of construction and maintenance techniques.

d. Development of techniques for camouflage of the barriers.

e. Use of barrier on sloped surfaces (slipperiness).

f. Evaluation against tracked vehicles. 
Table 1

Cone Index Measurements

\begin{tabular}{|c|c|c|c|c|c|c|}
\hline \multirow{2}{*}{$\begin{array}{l}\text { Depth } \\
\text { in. }\end{array}$} & \multicolumn{6}{|c|}{ Pit No. } \\
\hline & 1 & 2 & 3 & 4 & 5 & 6 \\
\hline 1 & 0 & 2 & 3 & 0 & 0 & 2 \\
\hline 2 & 0 & 2 & 2 & 0 & 0 & 2 \\
\hline 4 & 0 & 1 & 2 & 0 & 0 & 2 \\
\hline 6 & 0 & 0 & 2 & 0 & 0 & 1 \\
\hline 8 & 0 & 6 & 3 & 0 & 0 & 1 \\
\hline 10 & 0 & 12 & 3 & 0 & 0 & 0 \\
\hline 12 & 0 & 14 & 1 & 0 & 0 & 0 \\
\hline 14 & -- & -- & 6 & - & - & -- \\
\hline 16 & -- & -- & 13 & - & -- & -- \\
\hline
\end{tabular}

Table 2

Summary of Surface Drop, Inches

\begin{tabular}{|c|c|c|c|c|c|c|c|c|}
\hline \multirow{2}{*}{$\begin{array}{l}\text { Pit } \\
\text { No. }\end{array}$} & \multicolumn{8}{|c|}{ Days } \\
\hline & 1 & 5 & 10 & 15 & 20 & 25 & 30 & 35 \\
\hline 1 & 6.0 & 8.0 & 10.0 & 15.3 & 17.0 & 18.5 & 19.3 & 20.0 \\
\hline 2 & 3.9 & 6.3 & 9.5 & 11.3 & 12.5 & 13.0 & 13.5 & 13.5 \\
\hline 3 & 2.8 & 4.6 & 6.7 & 8.0 & 8.9 & 9.4 & 10.3 & 10.4 \\
\hline 4 & 0.0 & 0.8 & 1.0 & 0.9 & 2.8 & 4.3 & 6.0 & 8.0 \\
\hline 5 & 2.0 & 3.9 & 5.2 & 6.0 & 7.0 & 7.3 & 6.5 & 7.2 \\
\hline 6 & 0.5 & 1.2 & 1.5 & 1.9 & 2.2 & 2.5 & 2.5 & 2.5 \\
\hline
\end{tabular}

Table 3

Cone Index Measurements in Vehicle Barrier

\begin{tabular}{llllllllllll}
\hline & Cone & Index Measurements & for Depth, in. \\
\hline$\underline{0}$ & $\underline{2}$ & $\underline{4}$ & $\underline{6}$ & $\underline{8}$ & $\underline{10}$ & $\underline{12}$ & $\underline{14}$ & $\underline{16}$ & $\underline{18}$ & $\underline{20}$ & $\underline{24}$
\end{tabular}

$\begin{array}{llllllllllll}1 & 1 & 2 & 2 & 1 & 1 & 0 & 0 & 0 & -- & --\end{array}$ 


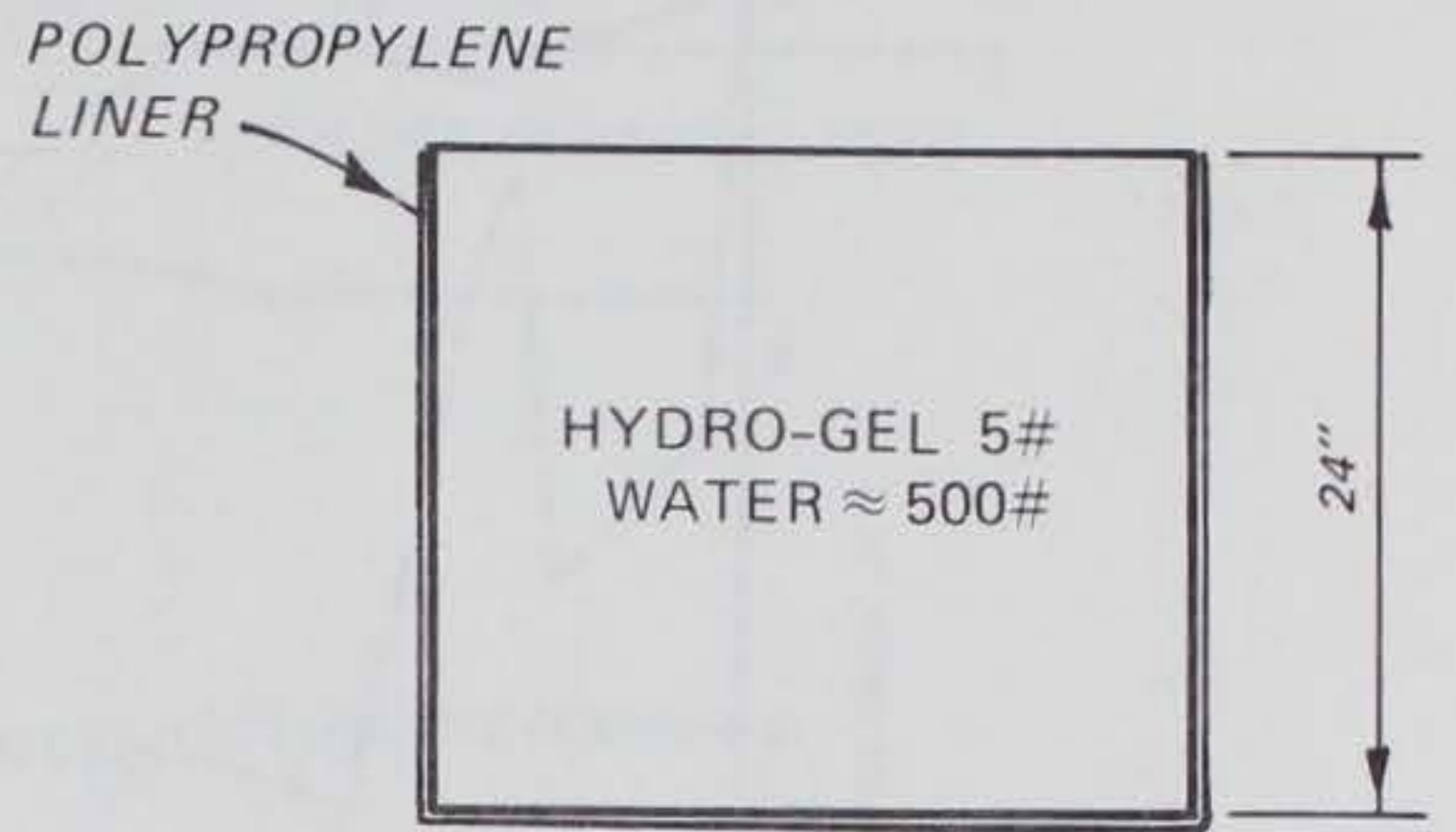

PIT 1

PIT 4

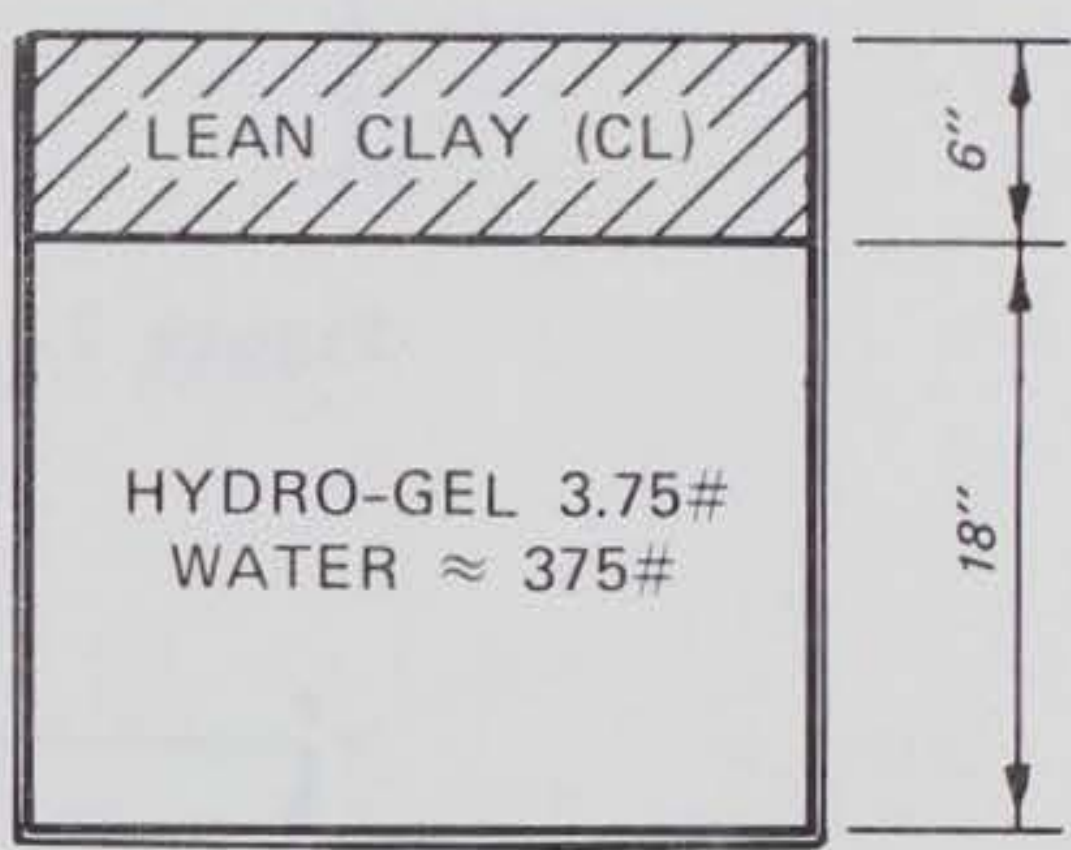

PIT 5

PIT 2

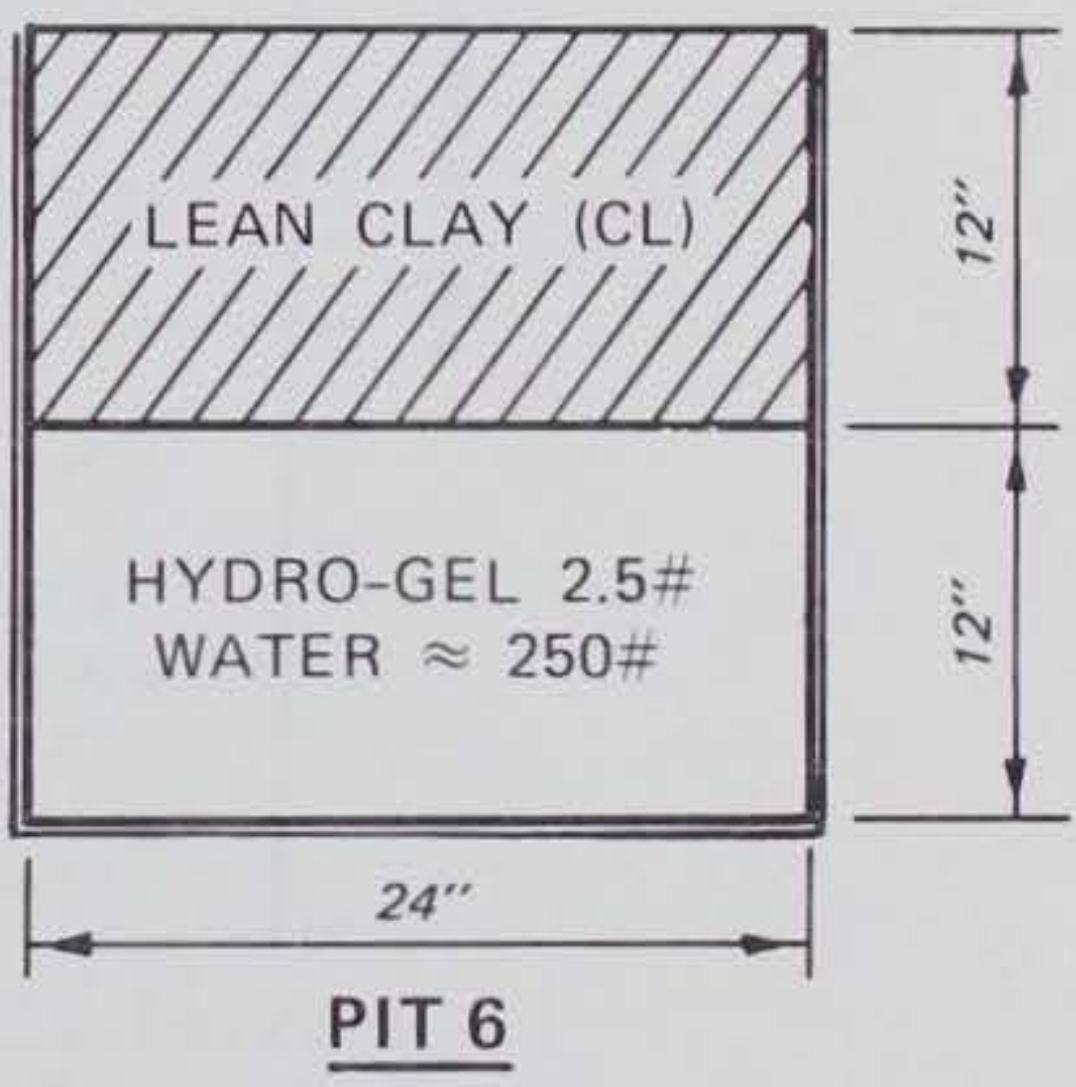

Figure 1. Cross sections of pits 


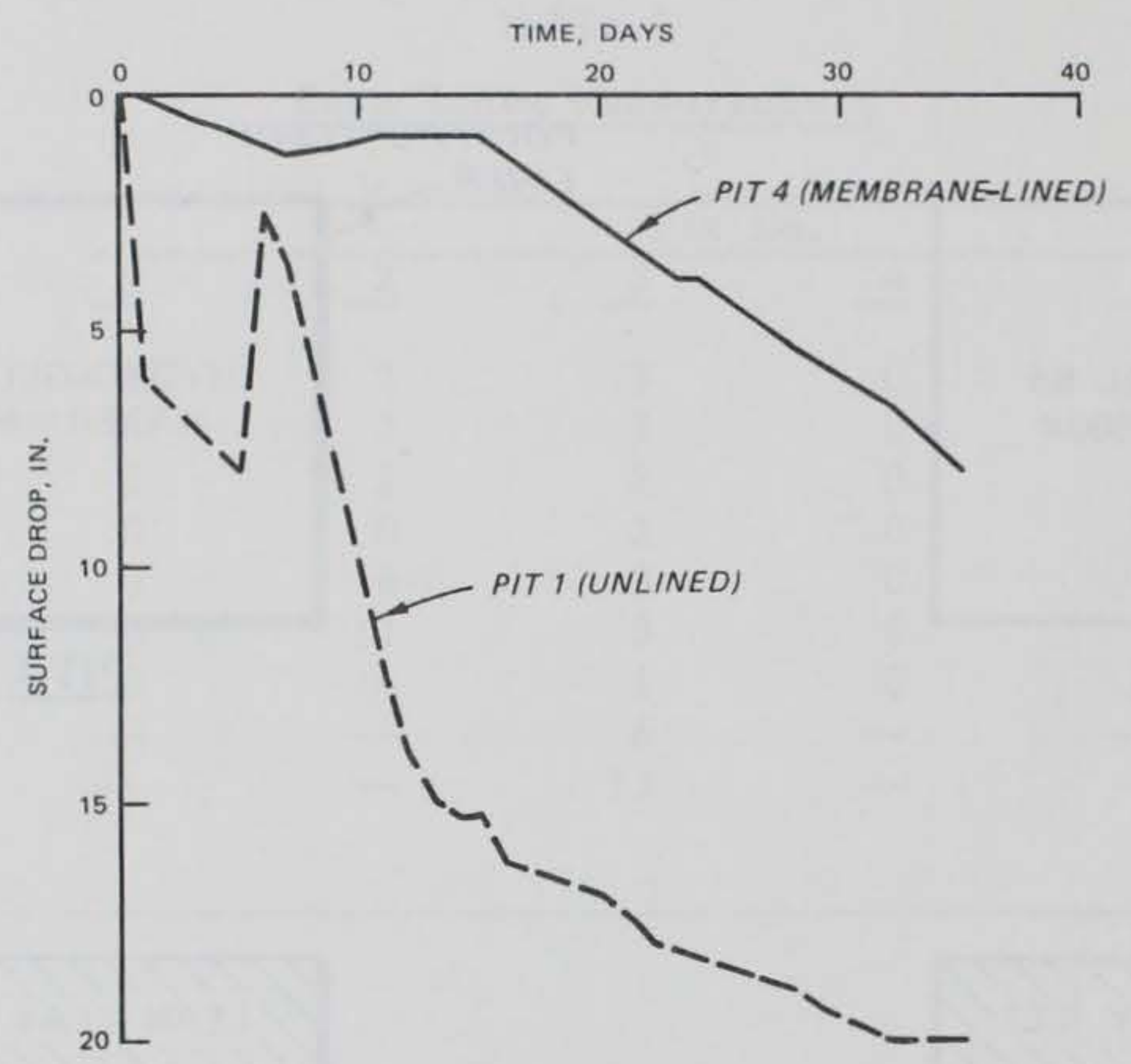

Figure 2. Comparison of surface drop, pits 1 and 4

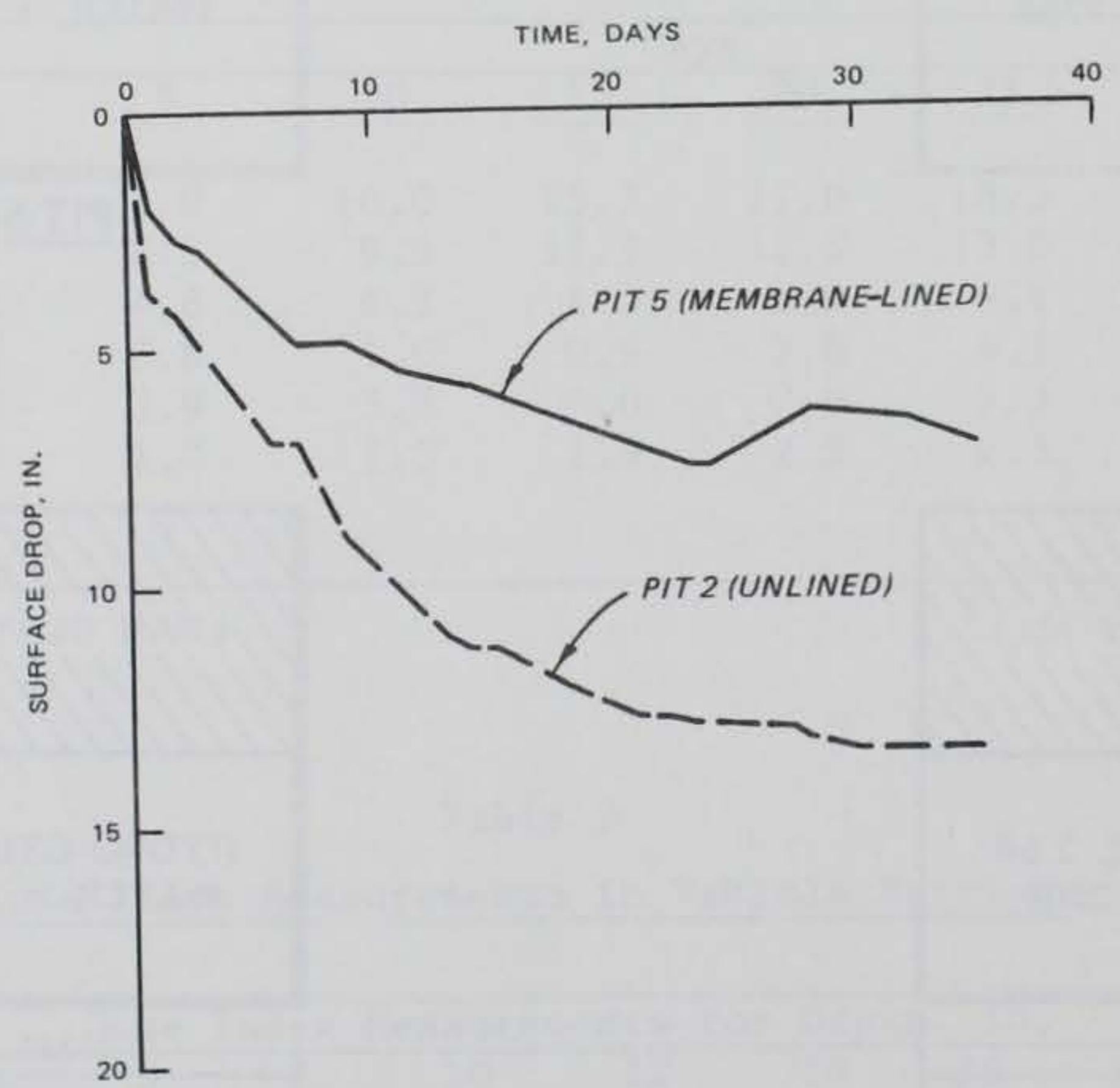

Figure 3. Comparison of surface drop, pits 2 and 5 
TIME, DAYS

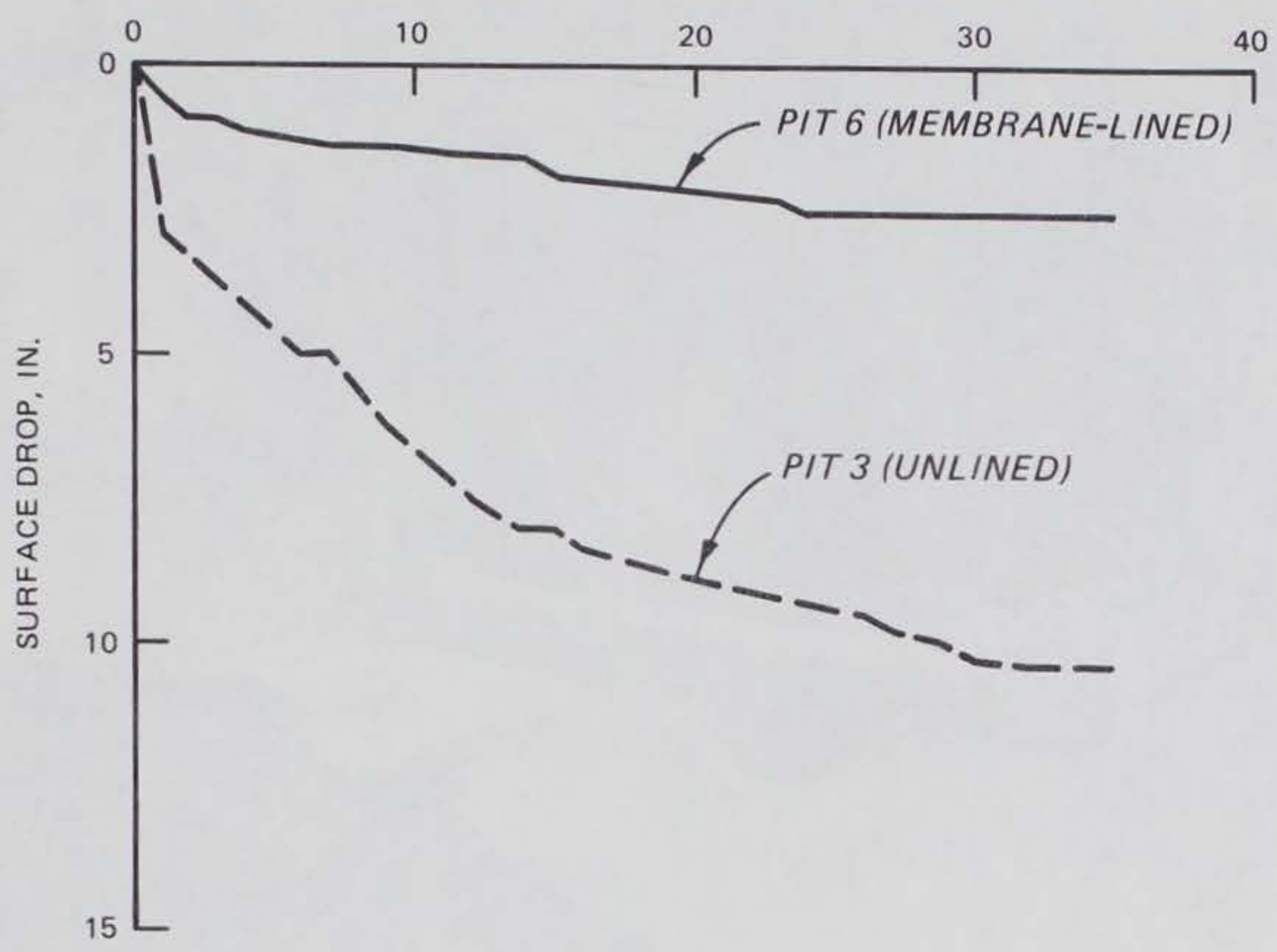

Figure 4. Comparison of surface drop, pits 3 and 6

DISTANCE, FT

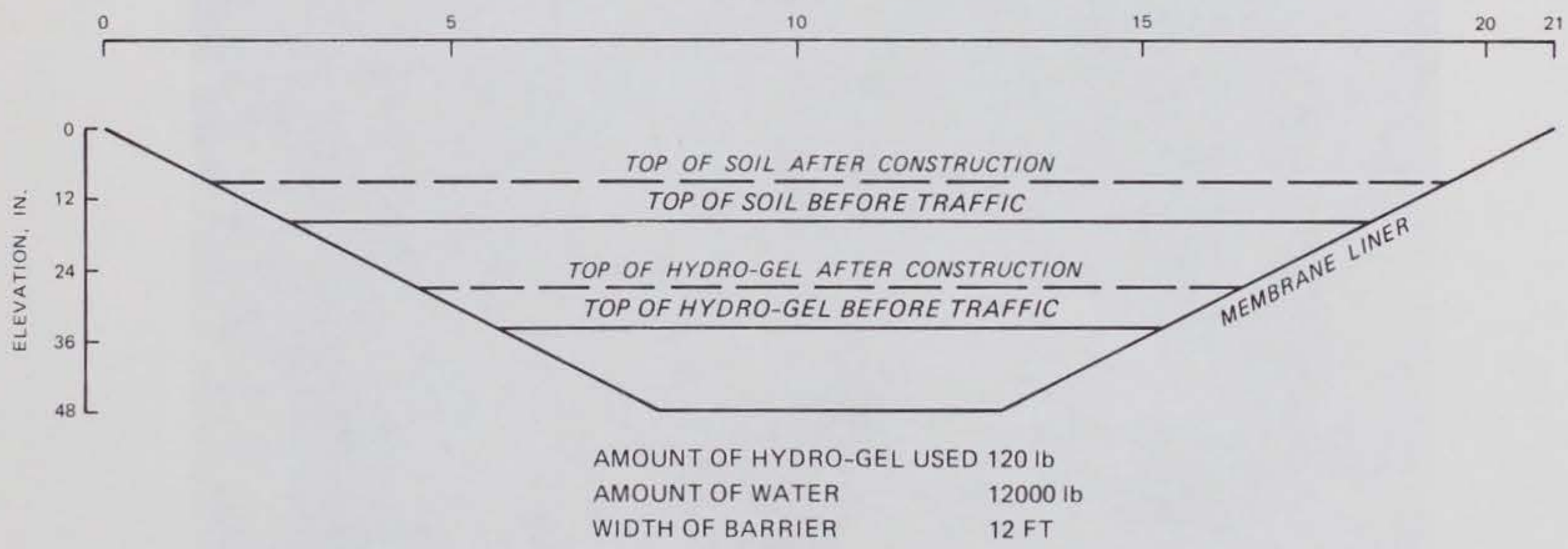

Figure 5. Cross section of vehicle barrier 


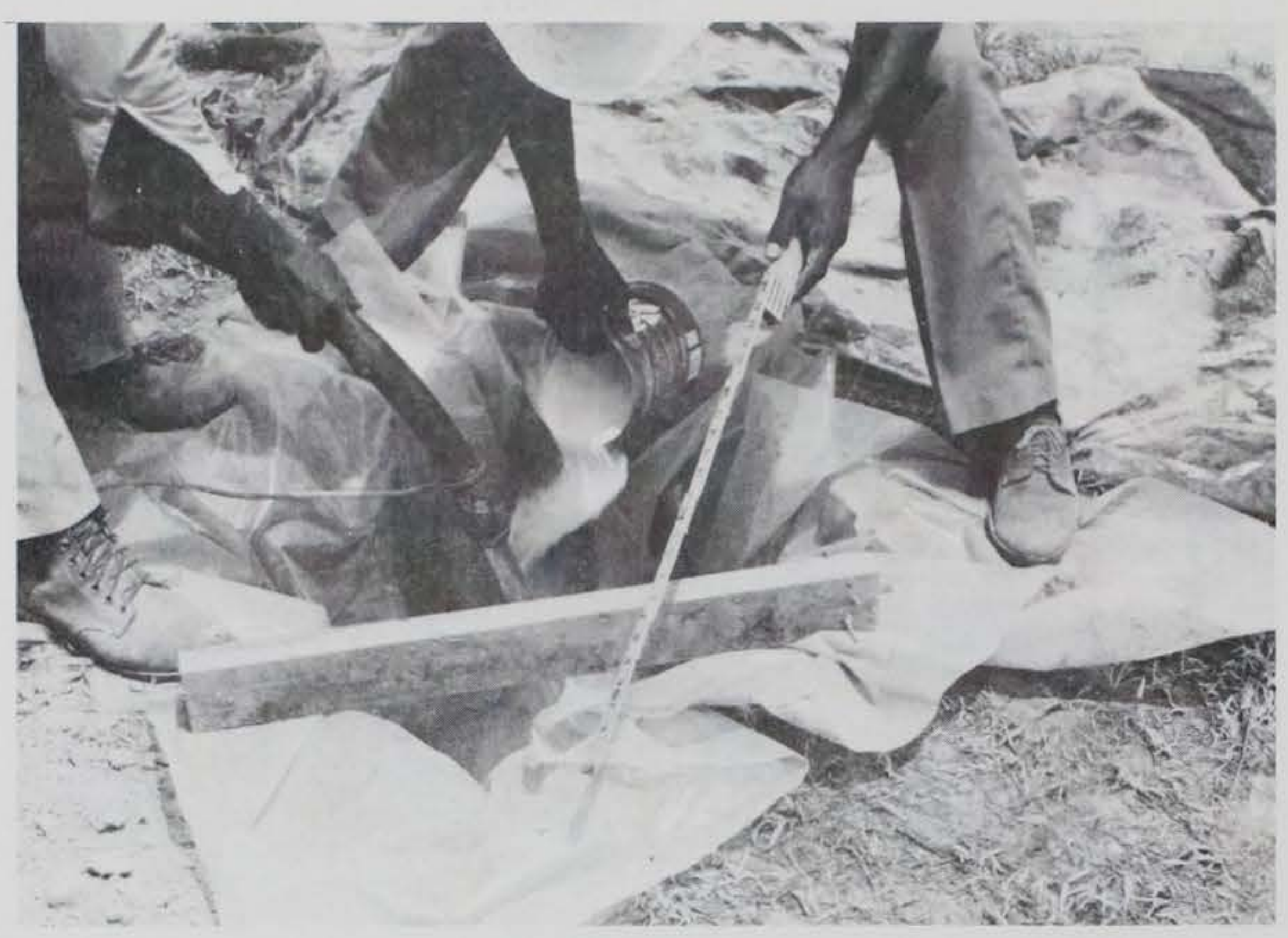

Photo 1. Pouring Hydro-Gel into a lined pit

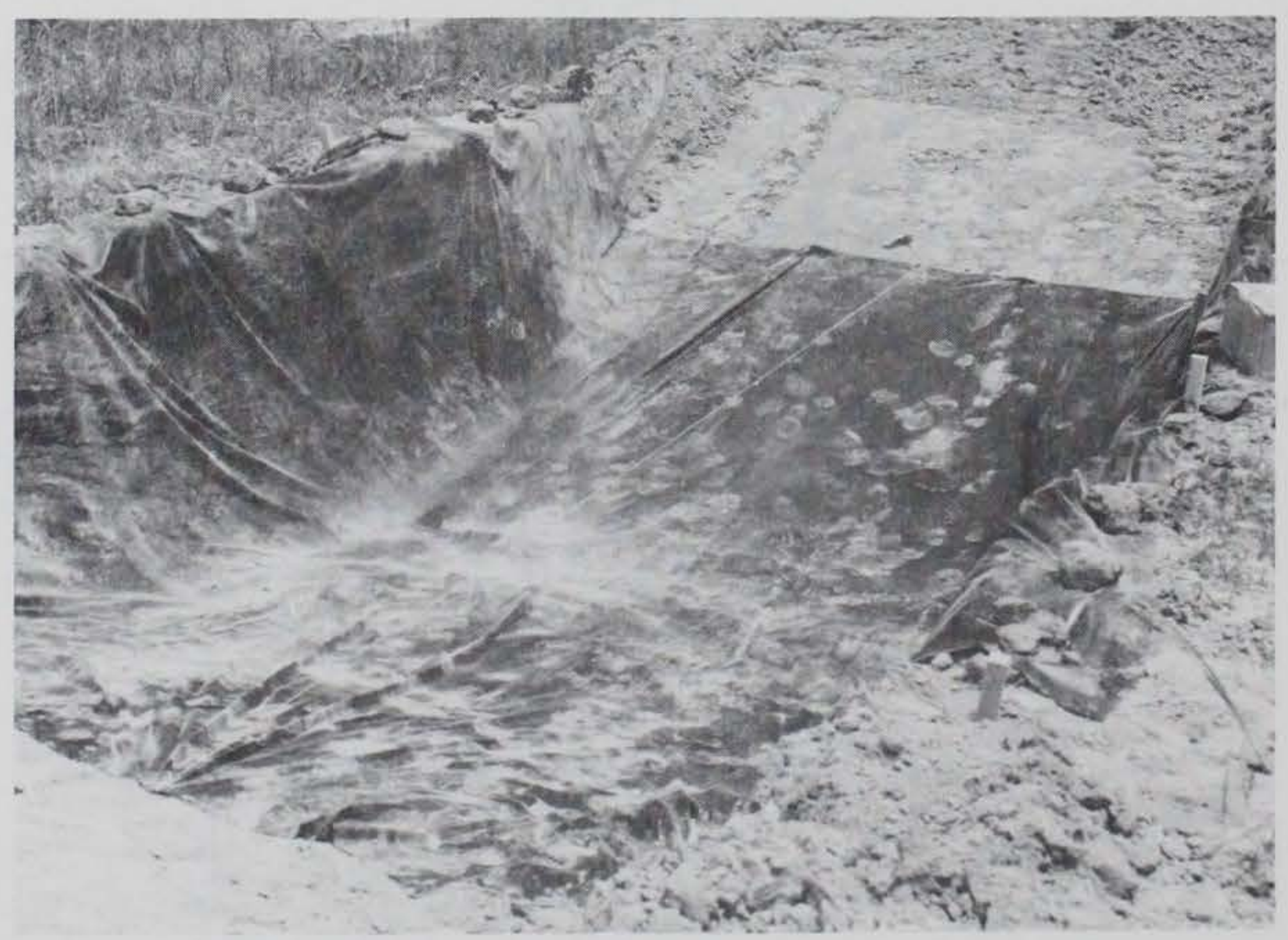

Photo 2. Lined vehicle barrier for Hydro-Gel pouring 


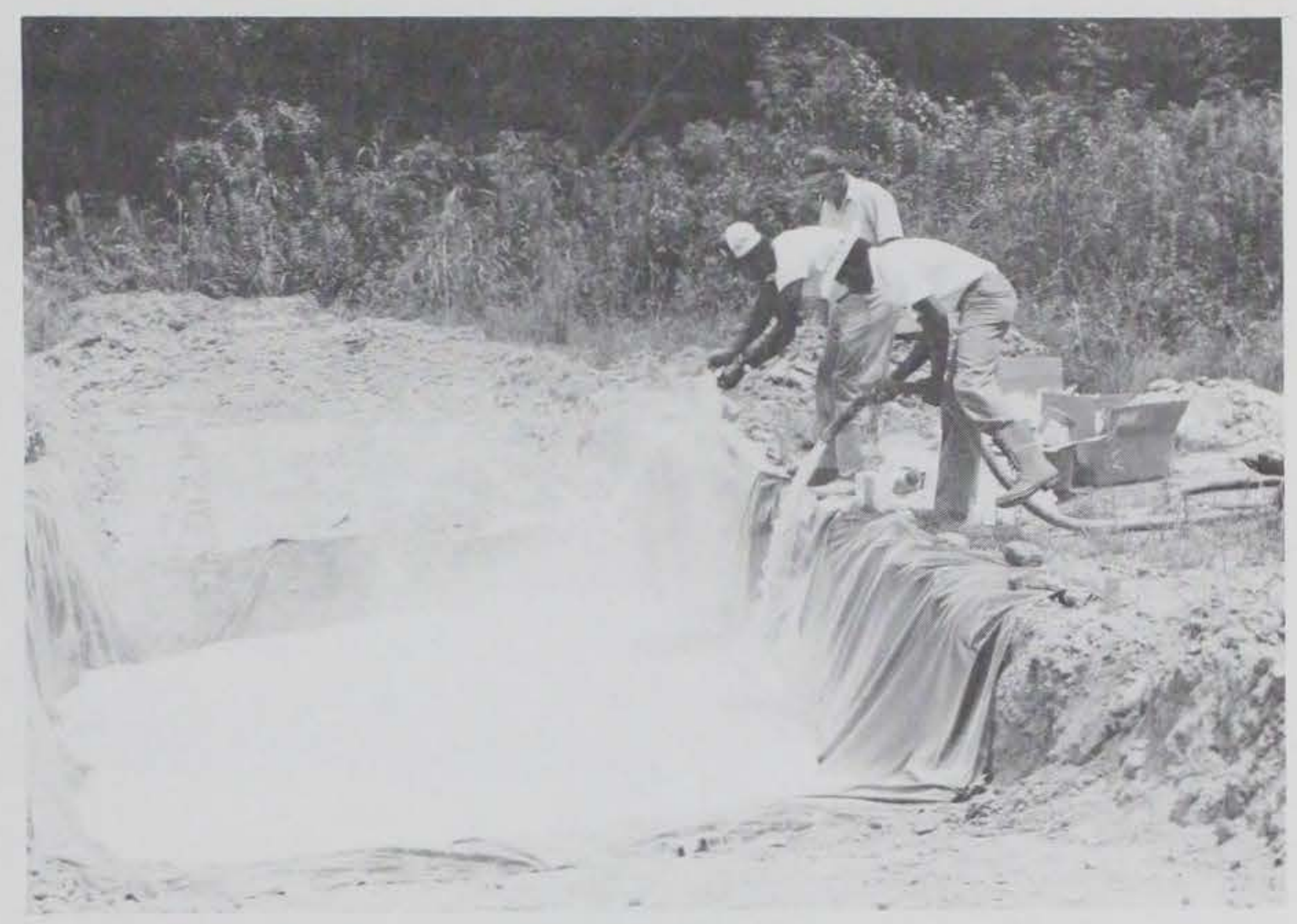

Photo 3. Pouring Hydro-Ge1 and water into barrier

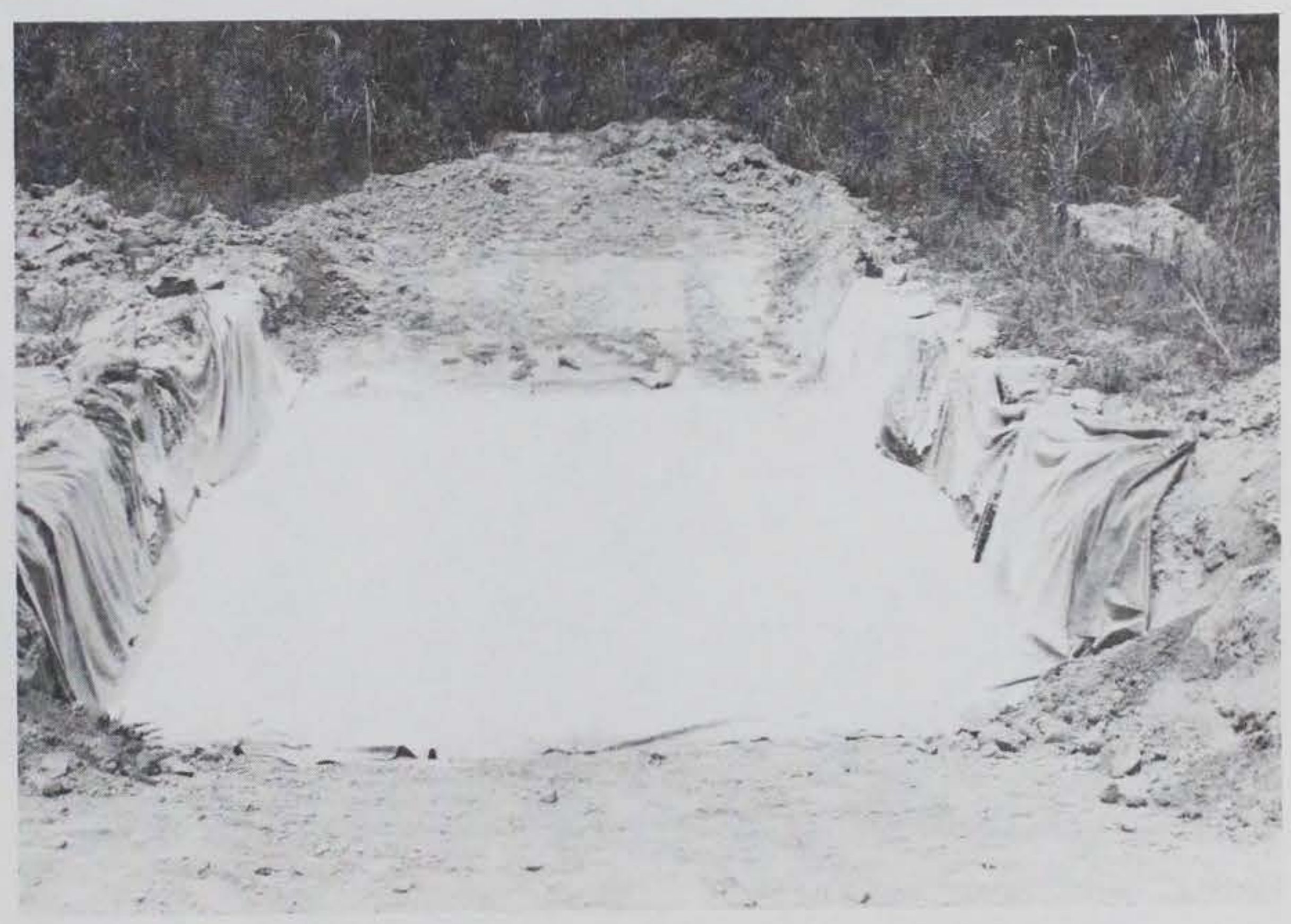

Photo 4. Hydro-Gel in place for soil covering 


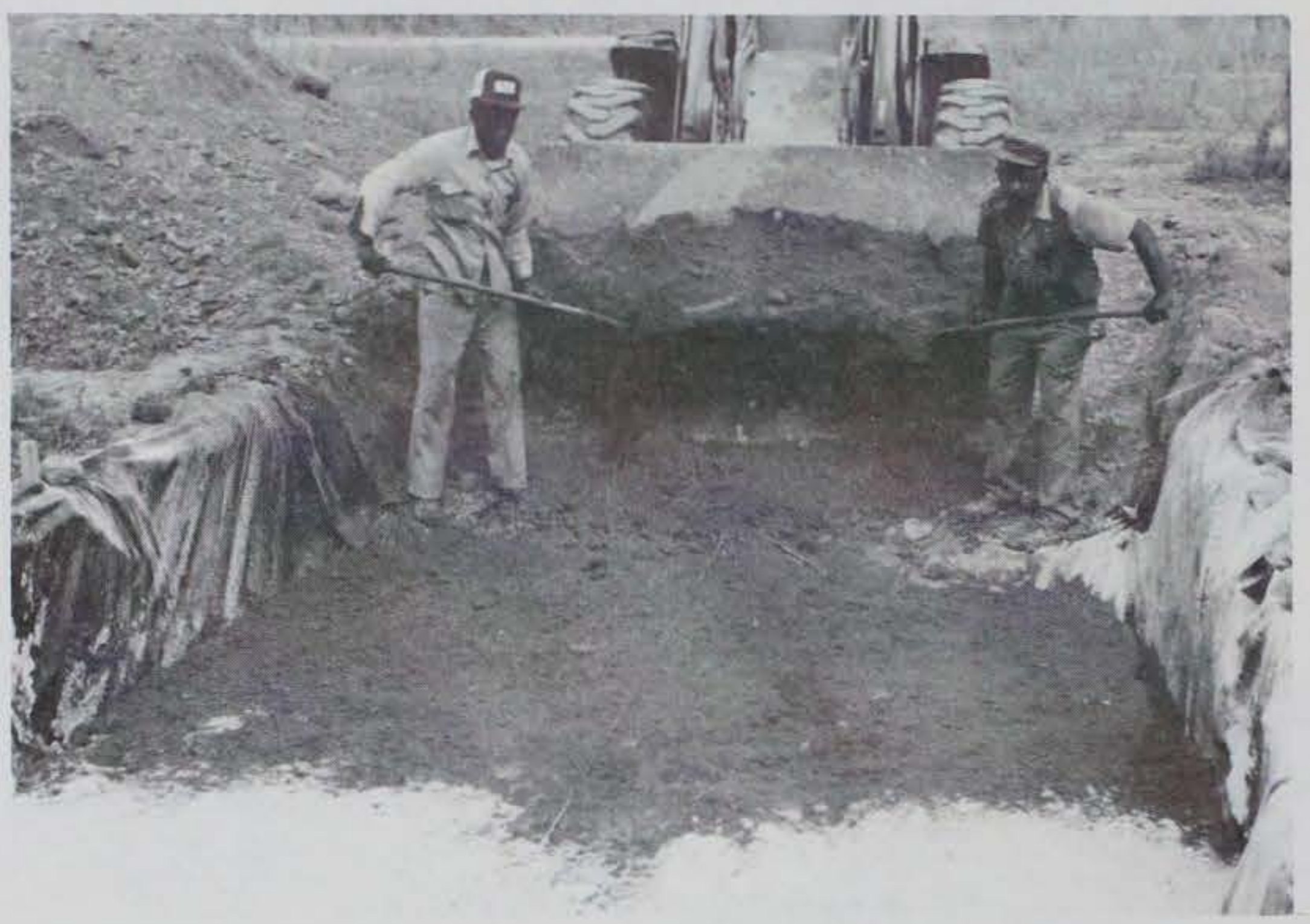

Photo 5. Placement of soil covering by hand

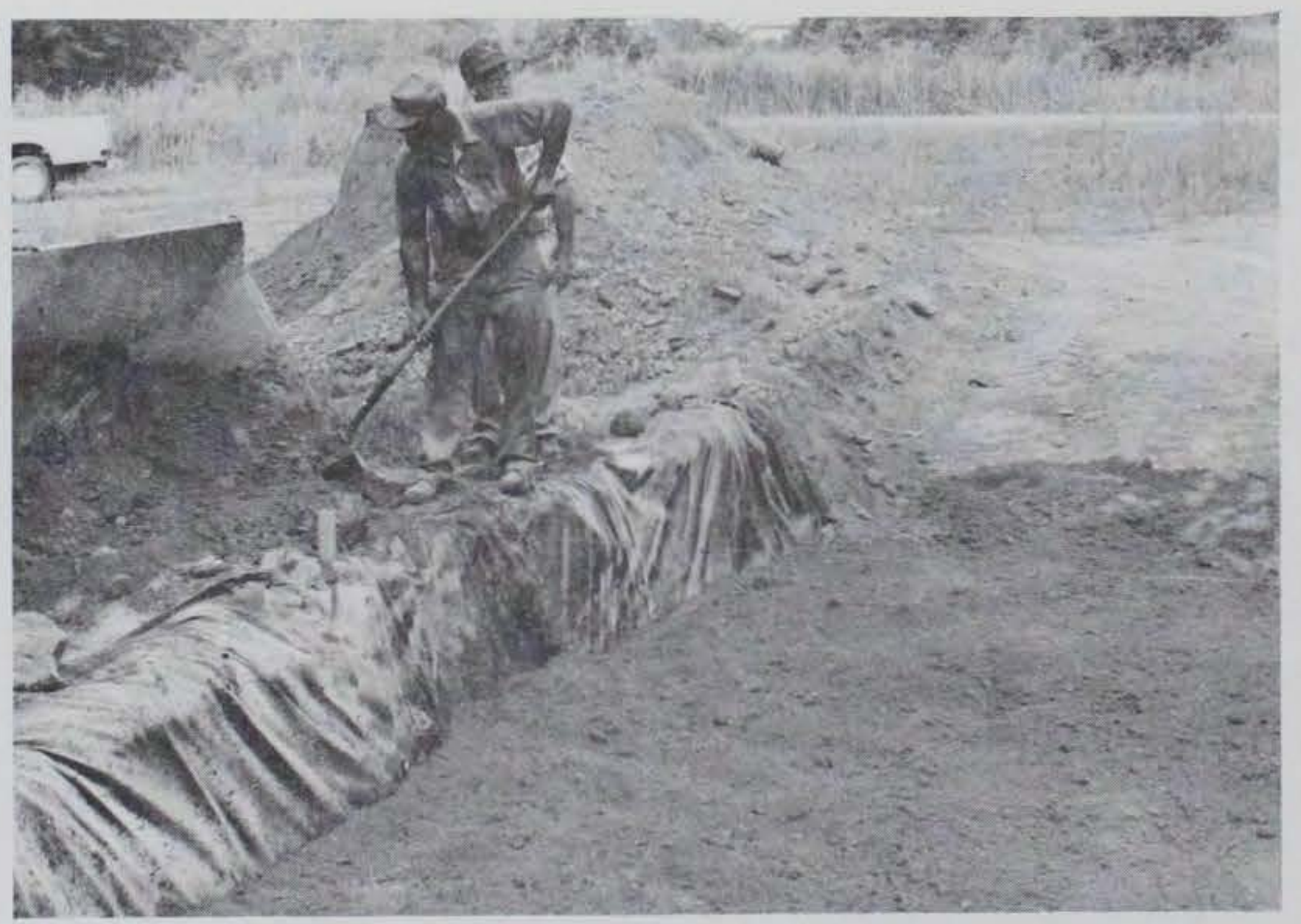

Photo 6. Soil covering to prevent displacement 


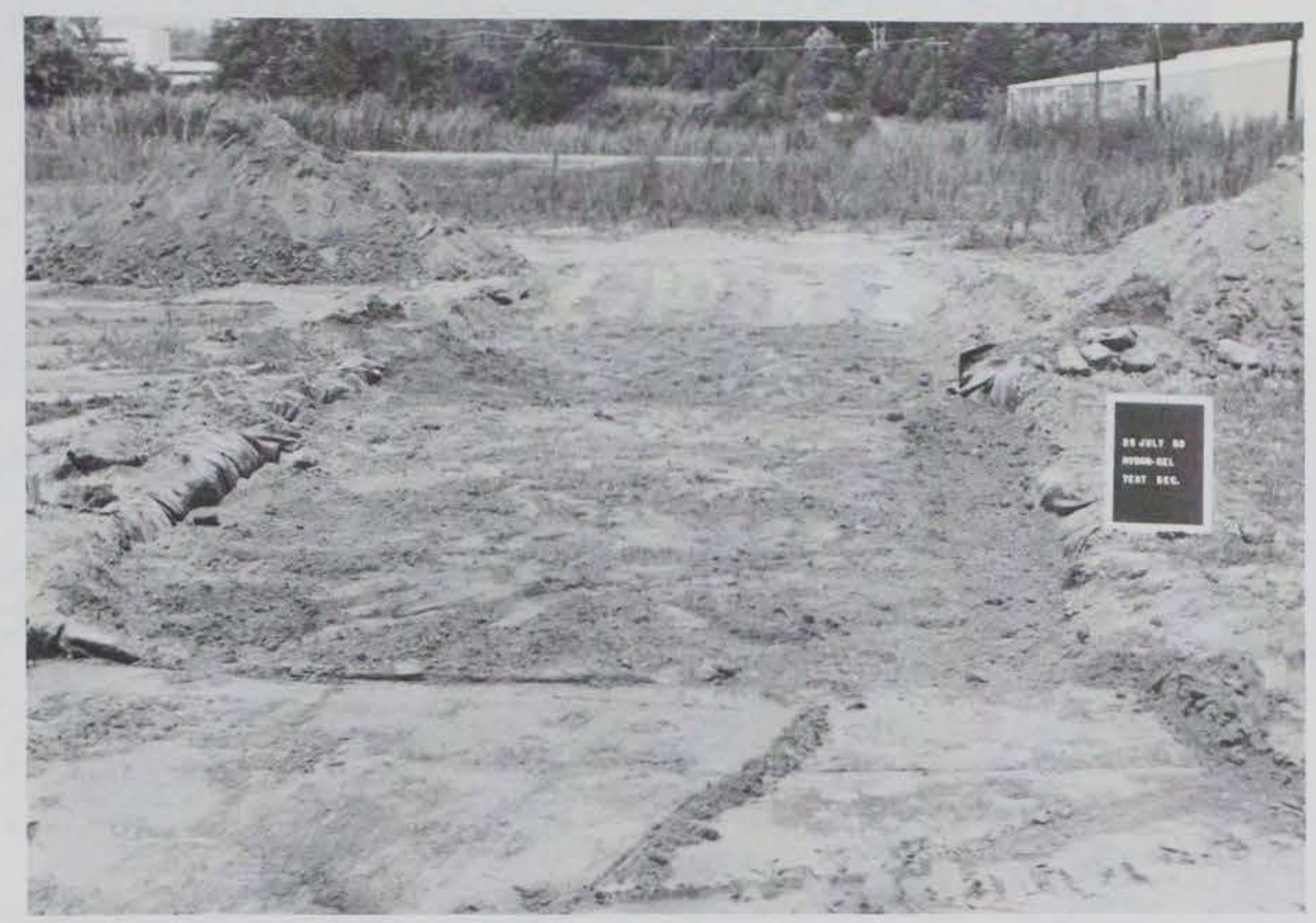

Photo 7. Completed barrier immediately after construction

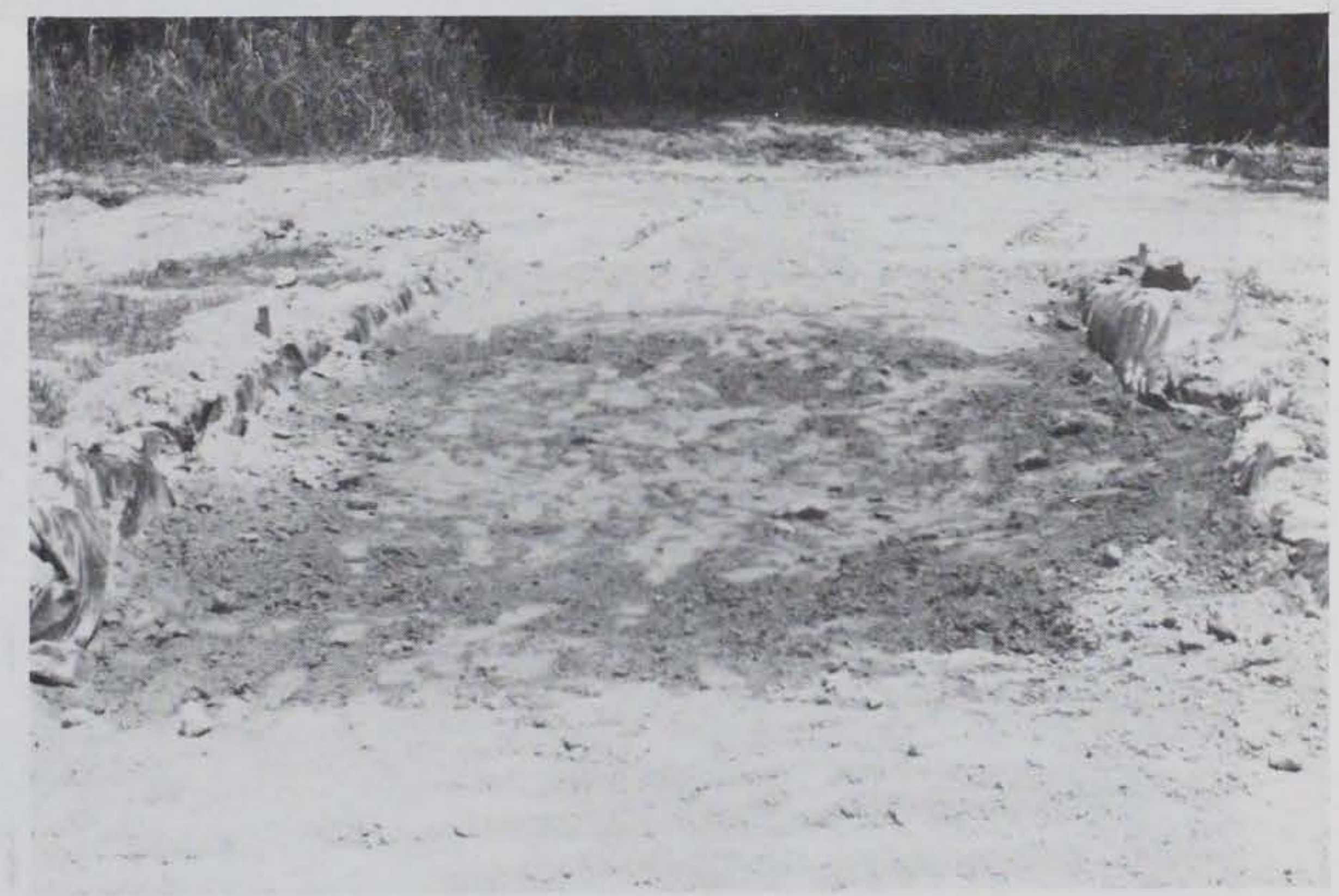

Photo 8. Vehicle barrier 7 days after construction 


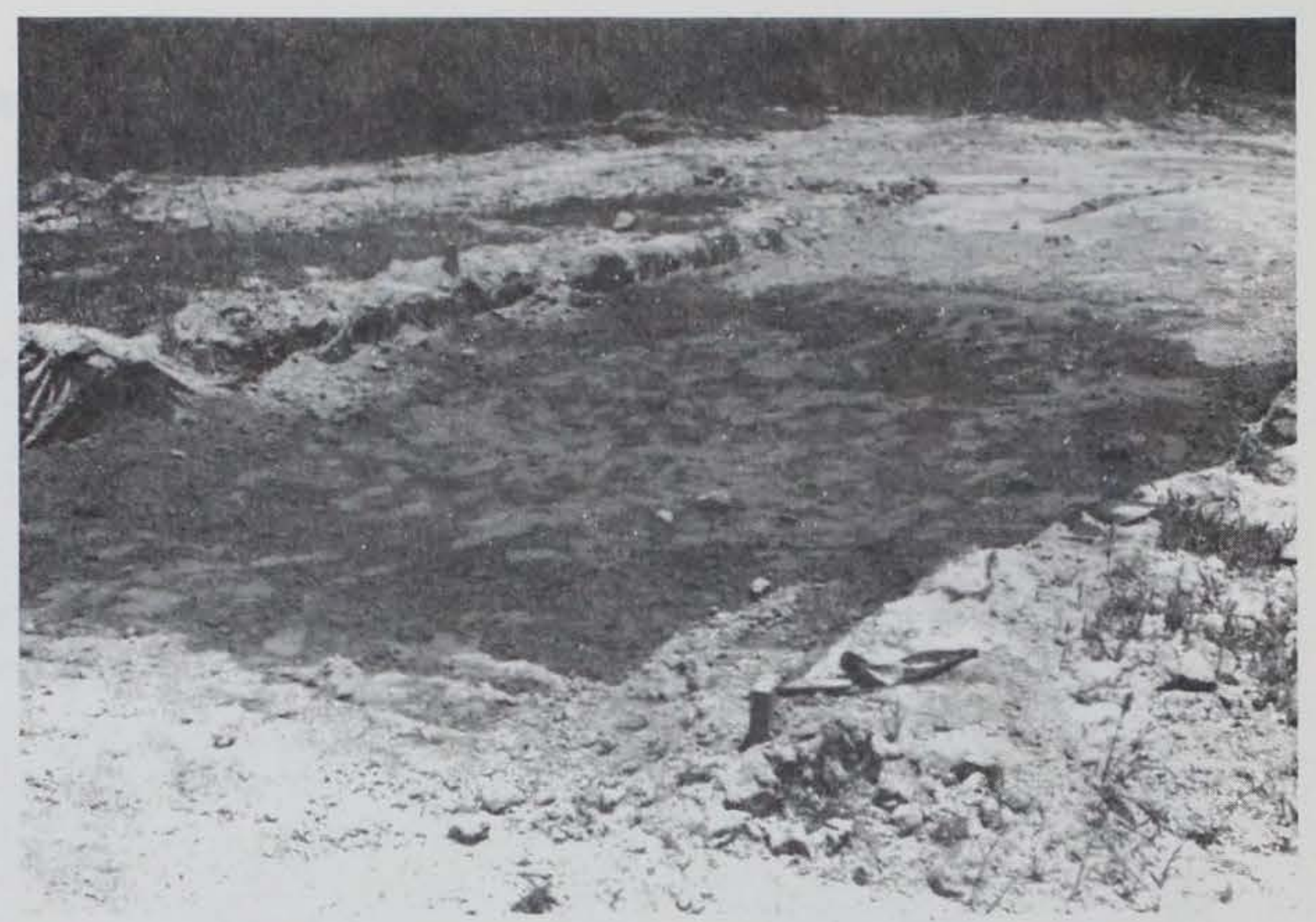

Photo 9. Vehicle barrier 14 days after construction

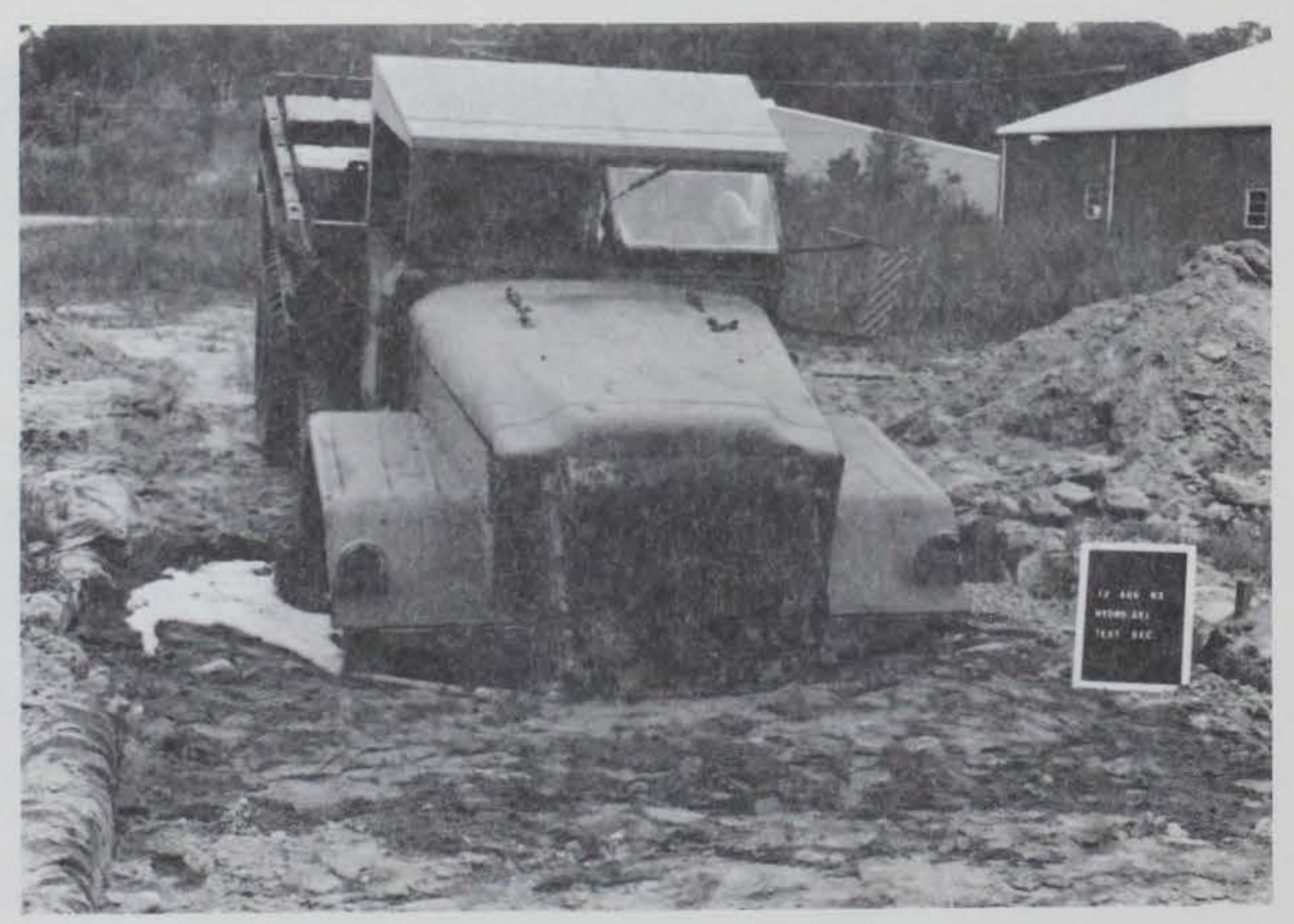

Photo 10. Five-ton military truck breaking through soil 


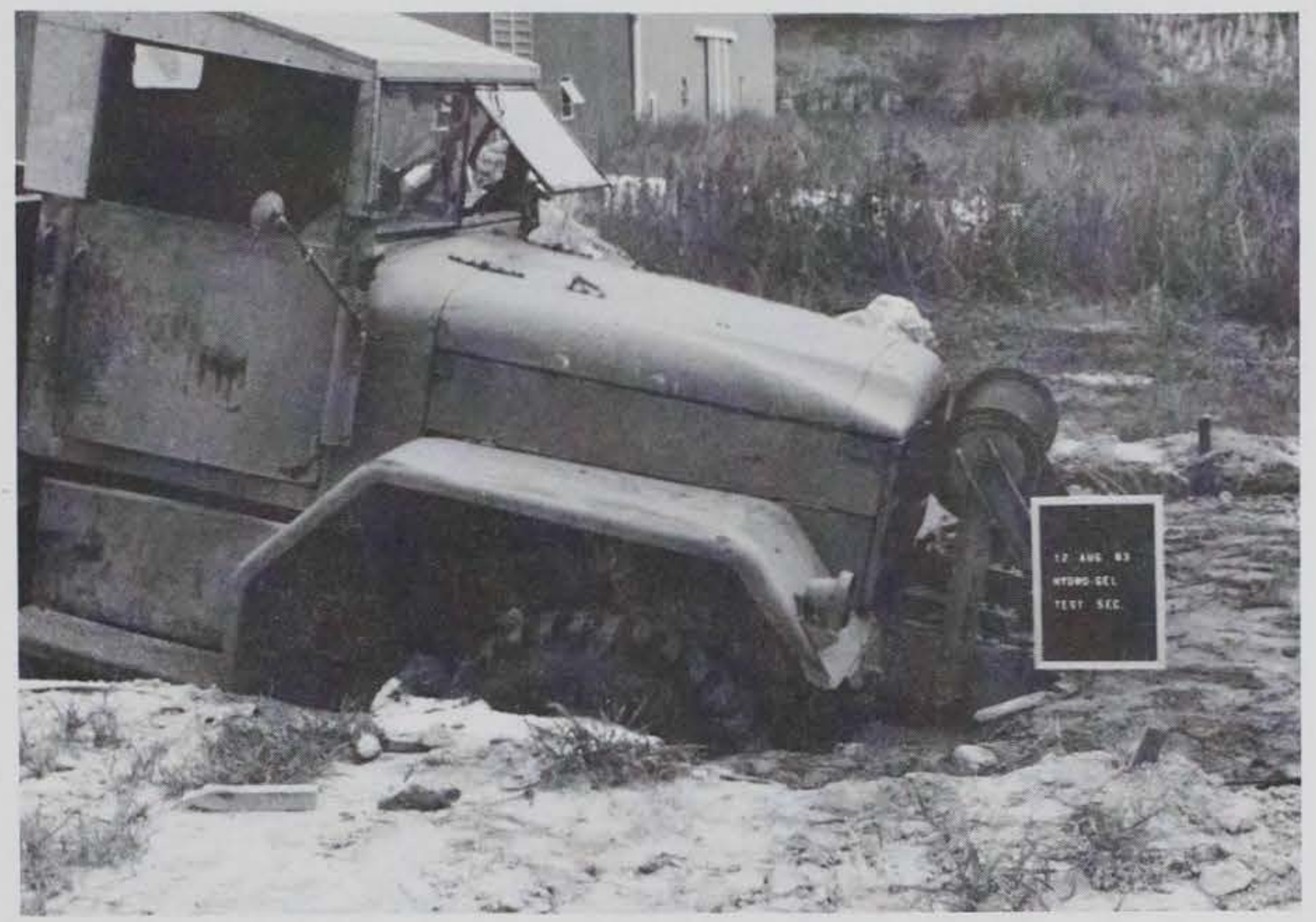

Photo 11. Five-ton military truck after breaking through soil 